\title{
Reciprocating versus Rotary instruments: a review
}

Flavia Villela Laurindo ${ }^{\mathrm{a}}$, José Antonio Poli de Figueiredo ${ }^{\mathrm{a}}$

\begin{abstract}
Objective: Literature started to point out essential parameters involving reciprocating instruments through clinical and laboratory essays. Looking into apical debris extrusion, incidence of instrument breakage, canal centering ability, apical zipping, a myriad of information has become available. The aim of this review is to revisit the literature and compare reciprocal and continuous rotation techniques.

Methods: A review of current literature may collect recent findings.

Conclusion: Reciprocating systems are similar in some aspects in comparison to rotational systems, with regards to cleaning ability, centered preparations, cleaning ability, reduction of Enterococcus faecalis and dentine defects. On the other hand, being single use and enhanced resistance to fatigue, together with novel methods to treat the alloy may lead to the thought that reciprocal systems are an excellent aid to root canal preparation. However, more needs to be understood about this new era of instruments to verify, long term and especially in vivo, the success and failure when these instruments are used.
\end{abstract}

Key words: Reciprocating systems; Rotational systems; Endodontics

\section{Instrumentos reciprocantes versus rotatórios: revisão de literatura}

\section{RESUMO}

Introdução: A literatura começou a apontar parâmetros essenciais envolvendo instrumentos reciprocantes através de ensaios clínicos laboratoriais. Pesquisando sobre a extrusão apical de detritos, incidência de instrumentos quebrados, capacidade de centralização do canal, uma infinidade de informações se torna disponível. O objetivo desta revisão é rever a literatura e comparar as técnicas de rotação recíproca e rotação continua.

Metodologia: Foi realizada uma revisão atualizada da literatura

Conclusão: Os sistemas reciprocantes são similares aos sistemas rotatórios em alguns aspectos, como por exemplo; capacidade de limpeza, preparações centralizadas, redução de Enterococcus faecalis e defeitos dentinários. Por outro lado, ser de uso único, a resistência à fatiga e o tratamento que recebe a aleação, fazem do sistema resiprocante excelente no preparo do canal radicular.

Palavras-chave: Instrumentação reciprocante; Instrumentação rotatória; Endodontia a School of Dentistry, Pontifical Catholic University of Rio Grande do Sul, Porto Alegre, RS, Brazil.

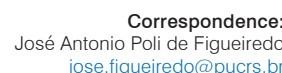

jose.figueiredo@pucrs.br

Received: May 29, 2015 Accepted: Fabruary 20, 2017

Conflict of Interests: The authors state that there re no financial and personal conflicts of interest that could have inappropriately influenced their work.

Copyright: @ 2016 Laurindo \& Figueiredo licensee EDIPUCRS.

This work is licensed under a Creative Commons Attribution 4.0 International License. 


\section{INTRODUCTION}

The popularization of use of nickel-titanium (NiTi) instruments for root canal preparation has brought greater predictability of this important phase of root canal treatment. Super-elasticity is the key for the superior properties of this alloy when compared to stainless steel instruments [1]. Engine-driven systems became a reality and constantly new systems are being launched in the dental market.

The risk of instrument fracture is probably the greatest disadvantage of NiTi regular use. If not removed, the piece that became retained may impair proper root canal system disinfection and cause failure [2,3].

The first rotary NiTi system was proposed by Dr. John McSpadden and reached the dental market in 1992. These instruments had 0.02 taper. In 1994 he added 0.04 and 0.06 tapers, which changed the ISO previous paradigm [4]. From then, various systems were used in a multitaper approach. The advantages were still not enough to avoid instrument fracture occurrence, A new type of instrumentation was suggested, based on alternated movement, known as reciprocation.

The principle of reciprocal movement is similar to a watch-winding hand motion, being used first with stainless steel instruments in 1958. Initially the available motors would alternate rotation equally clock and anticlockwise in $90^{\circ}$ angulations. Later, new motors would allow smaller angulations of $30^{\circ}$ clock and anticlockwise [4]. In 2008, a new concept of reciprocation was proposed by Dr. Ghassan Yared, using only one NiTi instrument, which at that stage was a 25/0.08 Protaper, and the clock and anticlockwise movements would alternate with different angulations for each move [5].

The proposed technique had a wide acceptance amongst endodontists, because it was advantageous with lower cost and time, as well as cyclic fatigue. The instrument in this technique should be used only once [6].

Staring from 2011, new systems were launched in the market, with new materials and designs, bringing up new perspectives of use in endodontology. Literature started to point out essential parameters through clinical and laboratory essays. Looking into apical debris extrusion, incidence of instrument breakage, canal centering ability, apical zipping, a myriad of information has become available. Therefore, a review of current literature may collect recent findings and help practitioners about this novelty. The aim of this review is to revisit the literature and compare reciprocal and continuous rotation techniques.

\section{Cleaning and shaping}

Shaping ability deriving from a preparation technique, either under rotary or reciprocating movement may influence the other steps of endodontic treatment: irrigation and root filling. Root anatomy, especially curvatures, is changed by endodontic instruments, with a tendency of rectification; however, ledges, zipping and other problems may arise and impose difficulties to the removal of infected tissue which could lead to failure. Predictability is one of the major aspects to be considered in root canal preparation.

You et al. [7] assessed Protaper shaping ability under continuous and reciprocating modes. They measured root volume, curvature and surface area through microtomography. They could not find differences between the techniques even with severe curves apically. Similarly, Franco et al. [8] tested FlexMaster system in Rotary and reciprocal movements. Minimal differences were found; Root centering ability was better with reciprocation, but taper was better achieved under continuous rotation.

Bürklein et al. [9] tested the cleaning ability of Reciproc and WaveOne, which are reciprocating, compared to rotary MTwo and Protaper. They found that the four systems were efficient in maintaining root curvature. Rotary MTwo and reciprocating Reciproc seemed to perform better at cleaning the root canal walls. Apparently the movement did not influence the final result. Various other studies compared cleaning and shaping abilities using different instruments of rotation and reciprocation, such as Protaper, Mtwo, WaveOne, Reciproc, Twisted File, OneShape, F360, but they all allowed satisfactory preservation of original shape and limited differences between techniques $[10,11,12]$.

\section{Debris compaction and apical extrusion}

Whenever a new instrumentation method is launched, it is expected that it is able to face contamination and cause minimal injury to periapical tissues, providing a favorable condition to repair and/or healing. These aspects are influenced by the ability of the instrument to remove organic debris and not compact them.

Although single instrumentation with reciprocating techniques perform faster, the amount of debris removal seems to be reduced $[13,14]$. Therefore one should consider the use of multitaper rotary instrumentation when preparing canals with high incidence of isthmuses and protrusions.

It is very unlikely that one can avoid apical debris extrusion, independently of the technique. This may lead to flare-ups. Al-Omari and Dummer [15] state that balanced force techniques reduce apical debris extrusion when compared to linear and continuous movements.

Bürklein and Schafer [16] compared apical extrusion from reciprocating WaveOne and Reciproc vs rotary Mtwo and ProTaper. They found that all systems caused apical extrusion, but rotary instrumentation had lower levels of extrusion. This contrasts with other studies that found better results with reciprocating instruments $[17,18]$.

\section{Reduction of Enteroccocus faecalis}

One of the main purposes of root canal treatment is microbial reduction and prevention of recontamination of the root canal system. Enteroccocus faecalis is commonly found in cases of persistent apical periodontitis and is associated with endodontic treatment failure [19].

Ferrer-Luque et al. [20] tested Enteroccocus faecalis reduction using Mtwo, Twisted File and WaveOne, collecting samples form root canal walls with paper points before and 
after instrumentation. Statistically reduction ability was not significant amongst groups. WaveOne had higher percentage of reduction, probably because of the taper, 0.08 compared to 0.06 of the other instruments. Machado et al. [21] and Martinho et al. [22] used endotoxins to test reduction and again no statistically significant diferences were found.

Oval canals were used in the study performed by Alves et al. [23]. They compared Reciproc and BioRace under molecular analysis using qPCR. They found both systems to be effective in reducing Enterococcus faecalis. Therefore the available literature may lead us to infer that the techniques under discussion do not interfere with the results on this bacterial species.

\section{Canal Anatomy Interference}

Canal volume is one of the variables used to assess dentine removal during root canal instrumentation. There is no consensus as to the ideal amount of dentine to be removed during preparation, but excessive instrumentation may lead to fragile root canal walls which could be more susceptible to fracture.

The amount of dentine to be removed in cervical and medium thirds should be enough to allow access to irrigating solutions to the apical third. When curvature comes into the equation, the final shape should allow rectification in such a way that stress is minimized and yet walls are kept strong enough to bear load and not fracture. At the apical third, especially at the foramen, preparation should not cause deviation or zipping and even perforations. These are associated with inefficient decontamination leading to persistent apical periodontitis.

Câmara et al. [24] assessed cross-sections of the three thirds of mesiobuccal canals prepared by one of three HERO systems (Hero 642, HeroShapers, Hero Apical), in continuous rotation. None of the systems was able to touch all the root canal walls. Another study [25] tested five Rotary systems and two manual systems (ProTaper, GT, ProFile, K-3, FlexMaster) and two manual NiTi systems (ProTaper, GT) as to the remaining dentine and canal diameter. Differences were not found amongst groups and all systems provided good preparation quality. Stern et al. [26] tested the centering ability of Rotary Protaper and Twisted Files and Protaper in reciprocating movement. Centering ability was provided by all techniques.

Several studies have compared rotary and reciprocating systems as to the occurrence of apical transportation and centering ability. Gergi et al. [27] compared Twisted File Adaptive, Reciproc and WaveOne, and found that Twisted File Adaptive showed the least apical transportation. This system is used in rotation until the instrument finds resistance, shifting automatically to reciprocation until the instrument is free again, returning to rotation. Also, they found this system to better maintain original anatomy with better centering ability [29]. However, Nazari et al. [29] found different results when comparing Reciproc and Twisted File Adaptive. According to this study, Reciproc provided less transportation than TF Adaptive.
Reciproc and MTwo have similar design, but one is meant to be used in reciprocation and the other in continuous rotation. In a study, MTwo seemed to provide greater apical transportation [30]. Other study compared Reciproc and BioRace and showed higher levels of transportation with the use of Reciproc [31].

A study assessed six \#25 systems (OneShape, Pro Taper Universal, Pro Taper Next X2, Reciproc, Twisted File Adaptive, SM2 WaveOne), finding no differences as to apical transportation, canal curvature and centering ability. Reciproc showed higher dentine removal ability [32]. OneShape, although showed lower centering ability, needed less time to prepare the canal than Reciproc and WaveOne [33].

The current literature does not provide solid evidence to infer that one system performs better to maintain original anatomy. Maybe centering ability is influenced by instrument design (taper, flexibility and cross-section). Operator factors, such as experience does not seem to influence quality $[34,35]$.

\section{Dentine defects}

The presence of microfractures and fissures in dentine may occur during instrumentation. The propagation of these defects by the incidence of repetitive load may lead to vertical fracture which may compromise tooth longevity. Bier et al. [36] showed greater microfractures when teeth were prepared with rotary instruments as compared to manual instrumentation. According to Kim et al. [37] the occurrence of defects could be associated with high torque and tapers.

Bürklein et al. [38] assessed dentine defects following the use of rotary Mtwo and Protaper vs reciprocating Reciproc and WaveOne. They found all techniques allowed the formation of defects, but this was more pronounced at the apical third with reciprocating instrumentation. On the other hand, Mahmoud et al. [39] compared Protaper in rotation and reciprocation, and reciprocating WaveOne in oval canals. They found the least defects and highest resistance to fracture when using WaveOne. This was confirmed by other study [40] that found Protaper to be more aggressive to produce microcracks when compared to WaveOne or manual Protaper. Again, more needs to be produced by the literature to allow better understanding the behavior of these instruments towards dentine.

\section{Resistance to breakage}

Although NiTi has numerous advantages against stainless steel, breakage is currently one of the greatest worries of practitioners. Instruments break with no apparent alterations, which make it more difficult to prevent accidents.

Instrument failures may be torsional and flexural. Torsional failures occur when instrument tip is stuck somewhere in the root canal wall and the motor keeps rotating the instrument into its long axis. Flexural failure occurs at the curvature generated by repetitive cycles of compression and tension, causing repetitive changes in the microstructure until it breaks [41]. It is estimated that $70 \%$ of breakages are flexural, 
There have been changes since the year 2000 in structure and treatment of NiTi instruments [43-47]. Thermal treatment is one of these changes. Also, nitrogen ion implantation has improved mechanical properties of the instruments [48, 49]. New designs together with these changes are bringing new generations of instruments.

M-Wire is a new NiTi alloy, using a special thermal process. Some studies assessed the effect of this treatment on breakage. Gambarini et al. [50] compared GTX that uses M-Wire with traditional K3, but did not find any difference as to resistance to fracture. However, other studies showed greater cyclic fatigue resistance using GTX compared to Profile, Endosequence and GT [51,52,53]. Bouska et al. [54] compared two M-Wire systems (GTX and ProFileVortex) and three traditional systems (Twisted File, Endosequence and Profile). The best results were the ones using M-Wire technology followed by Twisted File.

A new development was the R-phase, which is an intermediate phase with distortion of the austenitic phase, as a result of the repetitive cycles of heating and refrigeration, generating a different format that is intended to enhance resistance to cyclic fatigue and superelasticity [47]. Twisted file and $\mathrm{K} 3 \mathrm{XF}$ are amongst the instruments with this new technology. Pérez-Higeras et al. [55] compared K3XF and traditional K3 and Twisted File. R-Phase instrument K3XF showed greater resistance to fracture independently of the use, either in rotation or reciprocation.

Several studies report better behavior against breakage when reciprocating movement is performed. De-Deus et al. [56] compared Protaper F2 in simulated resin blocks in continuous or reciprocal rotation and reciprocation allowed greater resistance to breakage. You et al. [57] tested these instruments in extracted teeth and found that Protaper F2 could be used at least six times more under reciprocation than rotation, and time for preparation was also reduced under reciprocal movement.

Twisted File and Reciproc were also assessed under reciprocal and rotational motions, being both much more resistant to breakage under reciprocation $[58,59]$.

WaveOne and Reciproc are the most used reciprocal instruments. Comparative studies between these instruments found different results. Plotino et al. [60] and Perez-Hilgueras et al. [61] found better resistance to breakage with Reciproc. Pedullá et al. [62] found no statistical significant differences, whereas Kim et al. [63] found greater flexural resistance with Reciproc and greater torsional resistance with WaveOne.

\section{CONCLUSIONS}

Reciprocating systems are similar in some aspects in comparison to rotational systems, with regards to cleaning ability, centered preparations, cleaning ability, reduction of Enterococcus faecalis and dentine defects. On the other hand, being single use and enhanced resistance to fatigue, together with novel methods to treat the alloy may lead to the thought that reciprocal systems are an excellent aid to root canal preparation. However, more needs to be understood about this new era of instruments to verify, long term and especially in vivo, the success and failure when these instruments are used.

\section{REFERENCES}

1. Schäfer E, Schulz-Bongert U, Tulus G. Comparison of hand stainless steel and nickel titanium rotary instrumentation: a clinical study. J Endod 2004;30:432-5. https://doi.org/10.1097/00004770-200406000-00014

2. Haikel Y, Serfaty R, Bateman G, Senger B, Alleman C. Dynamic and cyclic fatigue of engine-driven rotary nickel-titanium endodontic instruments. J Endod 1999;25:434-440. https://doi.org/10.1016/S0099-2399(99)80274-X

3. Parashos $\mathrm{P}$, Messer $\mathrm{HH}$. Rotary NiTi instrument fracture and its consequences. J Endod 2006;32:1031-1043. https://doi.org/10.1016/j. joen.2006.06.008

4. Haapasalo M, Shen Y. Evolution of nickel-titanium instruments: from past to future. Endod Topics 2013;29:3-17. https://doi.org/10.1111/etp.12049

5. Yared G. Canal preparation using only one Ni-Ti Rotary instrument: preliminary observations. Int Endod J 2008;41:339-344. https://doi. org/10.1111/i.1365-2591.2007.01351.x

6. Paque F, Zehnder M, De-Deus G. Microtomography based comparison of reciprocating single-file F2 ProTaper technique versus rotary full sequence. J Endod 2011;37:1394-1397. https://doi.org/10.1016/j.joen.2011.06.031

7. You S, Kim H, Bae K, Back S, Kum K, Lee W. Shaping ability of reciprocating motion in curved root canals: Acomparative study with Mico-computed tomography. J Endod 2011;37:1296-1300. https://doi.org/10.1016/j. joen.2011.05.021

8. Franco V, Fabiani C, Taschieri S, Malentacca A, Bortolin M, Fabbro MD Investigation on the shaping ability of nickel-titanium files when used with a reciprocating motion. J Endod 2011;10:1398-401. https://doi. org/10.1016/j.joen.2011.06.030

9. Bürklein S, Hinschitza K, Dammaschke T, Schäfer E. Shapingablity and cleaning effectiveness of two single-file systems I severely curved root canals of extracted teeth:Reciproc and WaveOne versus Mtwo and ProTaper. Int Endod J 2012;45:449-61. https://doi.org/10.1111/j.13652591.2011.01996.x

10. Marzouk AM, Ghoneim AG. Computed Tomographic evaluation osf canal shape instrumented by different kinematics rotary nickel-titanium systems. J Endod 2013;39:906-9. https://doi.org/10.1016/j.joen.2013.04.023

11. Bürklein S, Benten S, Schäfee E. Shaping ability of different single-file systems in severely curved root canals of extracted teeth. Int Endod J.2013;46:590-7. https://doi.org/10.1111/iej.12037

12. Berutti E, Chiandussi G, Paolino DS, Scotti N, Cantatore G, Castellucci A, Pasqualini D. Canal shaping with WaveOne primary Reciprocating files and Pro Taper System: A Comparative study. J Endod 2012;38:505-9. https://doi.org/10.1016/j.joen.2011.12.040

13. Robinson JP, Lumley PJ, Cooper PR, Grover LM, Walmsley AD. Reciprocating root canal techinique induces greater debris accumulation than a continuous rotary techinique as assessed by 3-dimensional Micro-computed tomography. J Endod 2013;39:1067-70. https://doi. org/10.1016/j.joen.2013.04.003

14. De-Deus G, Barino B, Zamolyi RQ, et al. Suboptimal debridement quality produced by the single-file F2 ProTaper techinique in oval-shaped canals. J Endod 2010;36:1897-900. https://doi.org/10.1016/j.joen.2010.08.009

15. Al-Omari MA, Dummer PM. Canal blockage and debris extrusion with eight preparation techiniques. J Endod 1995;21:154-8. https://doi.org/10.1016/ S0099-2399(06)80443-7

16. Bürklein S, Schafer E. Apically extrude debris with reciprocating singlefile and full-sequence rotary instrumentation systems. J Endod 2012;38: 850-2. https://doi.org/10.1016/j.joen.2012.02.017

17. Tinoco JM, De-Deus G, Tinoco EMB, Saavedra F, Fidel RAS, Sassone LM Apical extrusion of bacteria when using reciprocating single-file and rotary multfile instrumentation systems. Int Endod J. 2014;47(6):560-6. https:// doi.org/ 10.1111/iej.12187.

18. Koçak S, Koçak MM, Saglam BC, Türker SA, Sagsen B, Er Ö. Apical extrusion of debris using self-adjusting file, reciprocating single-file, and 2 rotary instrumentation systems. J Endod. 2013;39:1278-80. https://doi. org/10.1016/j.joen.2013.06.013

19. Stuart CH, Scwartz SA, Beeson TJ, Owatz CB. Enterococcus faecalis:Its Role in root canal treatment failure and current concepts in retreatment. J Endod 2006;32[2]:93-8. https://doi.org/10.1016/j.joen.2005.10.049

20. Ferrer-Luque CM, Bejarano I, Ruiz-Linares M, Baca P. Reduction in Enteroccocus faecalis counts - a comparison between Rotary and reciprocating systems. Int Endod J. 2014;47:380-6. https://doi. org/10.1111/iej.12158 
21. Machado ME, Nabeshima CK, Leonardo MF, et al. Influence of reciprocating single file and Rotary instrumentation on bacterial reduction on infected root canals. Int Endod J 2013;46:1083-7. https://doi.org/10.1111/iej.12108

22. Martinho FC, Gomes APM, Fernandes AMM, Ferreira NS, Endo MS, Freitas LF, Camões ICG. Clinical comparision of the effectiveness of single-file reciprocating systems and rotary systems for removal of endotoxins and cultivable bacterial from primarily infected root canals. J Endod 2014;40:625-9. https://doi.org/10.1016/j.joen.2013.12.006

23. Alves FRF, Rôças IN, Almeida BM, Neves MAS, Zoffoli J, Siqueira Jr. JF. Quantitative molecular and culture analyses of bacterial elimination in ovalshaped root canals by a single-file instrumentation technique. Int Endod J 2012;45:871-7. https://doi.org/10.1111/j.1365-2591.2012.02045.x

24. Câmara AC, Aguiar CM, Figueiredo JAP. Assesment of deviation after biomechanical preparation of the coronal, middle and apical thirds of root canals instrumented with three hero rotary systems. J Endod 2007;33:1460-3. https://doi.org/10.1016/j.joen.2007.07.029

25. Brkanic T, Stojsin I, Zivkovic S, Vukoje K. Canal wall thickness after preparation with NiTi rotary files. Microscopy Research and Techinique 2012;75:253-57. https://doi.org/10.1002/jemt.21049

26. Stern S, Patel S, Foschi F, Sherriff M, Mannocci F. Changes in centring and shaping ability using three nickel-titanium instrumentation techniques analysed by micro-computed tomography. Int Endod J 2012;45:514-23. https://doi.org/10.1111/j.1365-2591.2011.02004.x

27. Gergi R, Arbab-Chirani R, Osta N, Naaman A. Micro-computed tomographic avaluation of canal transportation instrumented by different kinematics rotary nickel-titanium instruments. J Endod 2014;40:1223-7. https://doi.org/10.1016/j.joen.2014.01.039

28. Gergi R, Osta N, Bourbouze G, Zgheib C, Arab-Chirani R, Naaman A Effects of three nickel titanium instrument systems on root canal geometry assessed by micro-computed tomography. Int Endod J 2015;48:162-70. https://doi.org/10.1111/iej.12296

29. NazariMoghadam K, Shahab S, Rostami G. Canal transportation and centering ability of twisted file and reciproc: a cone-beam computed tomography assessment. Iran Endod J 2014:9:174-9.

30. Hwang YH, Bae KS, Baek SH, Kum KY, Lee W, Shon WJ, Chang SW Shaping ability of the conventional nickel-titanium and reciprocating nickel-titanium file systems: a comparative study using micro-computed tomography. J Endod 2014;40:1186-9. https://doi.org/10.1016/j. joen.2013.12.032

31. Nabavizadeh M, Abbaszadegan A, Khojastepour L, Amirhosseini M, Kiani E. A comparison of apical transportation in severely curved canals induced by reciproc and biorace systems. Iran Endod J 2014;9:117-22.

32. Capar ID, Ertas H, Ok E, Arslan H, Ertas ET. Comparative study of different novel nickel-titanium rotary systems for root canal preparation in severely curved root canals. J Endod 2014:40:852-6. https://doi.org/10.1016/j. joen.2013.10.010

33. Saber SE, Nagy MM, Schäfer E. Comparative evaluation of the shaping ability of WaveOne, Reciproc and OneShapes single-file systems in severely curved root canals of extracted teeth. Int Endod J 2015;48: 109-14. https://doi.org/10.1111/iej.12289

34. Goldberg M, Dahan S, Machtou P. Centering ability and influence of experience when using WaveOne single-file technique in simulated canals. Int J Dent 2012. https://doi.org/10.1155/2012/206321

35. Muñoz E, Forner L, Llena C. Influence of operator 's experience on root canal shaping ability with a rotary nickel-titanium single-file reciprocating motion system. J Endod 2014;40:547-50. https://doi.org/10.1016/j.joen.2013.08.027

36. Bier CA, Shemesh H, Tanomaru-Filho M, Wesselink PR, Wu Mk. The ability of different nickel-titanium Rotary instruments to induce dentinal damage during canal preparation. J Endod 2009;35:236-8. https://doi. org/10.1016/j.joen.2008.10.021

37. Kim HC, Lee MH, Yum J, Versluis A, Lee CJ, Kim BM. Potential relationship between design of nickel-titanium Rotary instruments and vertical root fracture. J Endod 2010;36:1195-9. https://doi.org/10.1016/j.joen.2010.02.010

38. Bürklein $S$, Tsotsis $P$, Schafer $E$. Incidence of dentinal defects after root anal preparation:reciprocating versus rotary instrumentation. J Endod 2013;39:501-4. https://doi.org/10.1016/j.joen.2012.11.045

39. Nasr HMAE, Kader KGAE. Dentinal damage and fracture resistance of oval roots prepared with single-file systems using different kinematics. J Endod 2014;40:849-51. https://doi.org/10.1016/j.joen.2013.09.020

40. Ashwinkumar V. Krithikadatta J, Surendran S, Velmurugan N. Effect of reciprocating file motion on microcrack formation in root canals: an SEM study. Int Endod J 2014;47:622-7. https://doi.org/10.1111/iej.12197

41. Haikel $Y$, Serfaty R, Batemann G, Senger B, Allemann C. Dynamic and cyclic fatigue of engine-driven rotary nickel-titanium endodontic instruments. J Endod 1999;25:434-40. https://doi.org/10.1016/S00992399(99)80274-X

42. Parashos P, Gordon I, Messer HH. Factors influencing defects of rotary nickel-titanium endodontic instruments after clinical use. J Endod 2004;30:722-5. https://doi.org/10.1097/01.DON.0000129963.42882.C9
43. Kuhn G, Tavernier B, Jordan L. Influence of structure on nickel-titanium endodontic instrument failure. J Endod 2001;27:516-20. https://doi. org/10.1097/00004770-200108000-00005

44. Kuhn G, Jordan L. Fatigue and mechanical properties of nickeltitanium endodontic instruments. J Endod 2002;28:716-20. https://doi. org/10.1097/00004770-200210000-00009

45. Hayashi $Y$, Yoneyama T, Yahata $Y$, et al. Phase transformation behavior and bending properties of hybrid nickel-titanium rotary endodontic instruments. Int Endod J 2007;40:247-53. https://doi.org/10.1111/j.13652591.2007.01203.x

46. Yahata $Y$, Yoneyama T, Hayashi $Y$ et al. Effect of heat treatment on transformation temperatures and bending properties of nickel-titanium endodontic instruments. Int Endod J 2009:42:621-6. https://doi. org/10.1111/j.1365-2591.2009.01563.x

47. Shen $Y$, Zhou H, Zhen $Y$, Peng B, Haapasalo M. Current Challenges and concepts of the thermomechanical treatment of nickel-titanium instruments. J Endod 2013;39:163-72. https://doi.org/10.1016/j. joen.2012.11.005

48. Santos M, Gavini G, Siqueira EL, Costa C. Effect of nitrogen ion impantation on the flexibility of rotary nickel-titanium instruments. J Endod. 2012;38:673-5. https://doi.org/10.1016/j.joen.2012.01.012

49. Gutmann JL, Gao Y. Alteration in the inherent metallic and surface properties of nickel-titanium root canal instruments to enhance performance, durability and safety: a focused review. Int Endod J 2012;45:113-28. https://doi.org/10.1111/j.1365-2591.2011.01957.x

50. Gambarini G, Grande MN, Plotino G, et al. Fatigue resistance of enginedriven rotary nickel-titanium instruments produced by new manufacturing methods. J Endod 2008;34:1003-5. https://doi.org/10.1016/j. joen.2008.05.007

51. Johnson E, Lloyd A, Kuttler S, Namerow K. Comparison between a novel nickel-titanium alloy and 508 nitinol on the cyclic fatigue life of Profile 25/04 rotary instruments. J Endod 2008;34:1406-9. https://doi.org/10.1016/j. joen.2008.07.029

52. Larsen CM, Watanabe I, Glickman GN, He J. Cyclic fatigue analysis of a new generation of nickel-titanium rotary instruments. J Endod 2009;35:401-3. https://doi.org/10.1016/j.joen.2008.12.010

53. Al-Hadlaq SMS, Al Jarbour FA, Al Thumairy RI. Evaluation of cyclic flexural fatigue of M-wire nickel-titanium rotary instruments. J Endod 2010;36: 305-7. https://doi.org/10.1016/j.joen.2009.10.032

54. Bouska J, Justman B, Williamson A, DeLong C, Qian F. Resistance to cyclic fatigue failure of a new endodontic rotary file. J Endod 2012;38:6679. https://doi.org/10.1016/j.joen.2012.01.016

55. Pérez-Higueras JJ, Arias A, Macorra JC. Cyclic fatigue resistence of K3 K3XF, and Twisted File nickel-titanium files under continuous rotation or reciprocating motion. J Endod. 2013;39:1585-8. https://doi.org/10.1016/j. joen.2013.07.020

56. De-Deus G, Moreira EJL, Lopes HP, Elias CN. Extended cyclic fatigue life of F2 ProTaper instruments used in reciprocating movement. Int Endod J 2010;43:1063-8. https://doi.org/10.1111/j.1365-2591.2010.01756.x

57. You S, Bae Y, Baek S, Kum K, Shon W, Lee W. Lifespan of one nickeltitanium rotary file with reciprocating motion in curved root canals. J Endod 2010;36:1991-4. https://doi.org/10.1016/j.joen.2010.08.040

58. Gambarini G, Gergi G, Naaman A, Osta N, Al Sudani D. Cyclic fatigue analysis of twisted file rotary $\mathrm{NiTi}$ instruments used in reciprocating motion. Int Endod J 2012;45:802-6. https://doi.org/10.1111/j.13652591.2012.02036.x

59. Gavini G, Caldeira CL, Akisue E, Candeiro GTM, Kawakami AS. Resistence of flexural fatigue of reciproc R25 files under continuos rotation and reciprocating movement. J Endod 2012;38:684-7. https:// doi.org/10.1016/j.joen.2011.12.033

60. Plotino G, Grande NM, Testarelli L, Gambarini G. Cyclic fatigue of Reciproc an WaveOne reciprocating instruments. Int Endod J 2012;45:614-18. https://doi.org/10.1111/j.1365-2591.2012.02015.x

61. Arias A, Perez-Higueras JJ, Macorra JC. Differences in cyclic fatigue resistance at apical and coronal levels of Reciproc and WaveOne new files. J Endod 2012:38:1244-8. https://doi.org/10.1016/j.joen.2012.05.022

62. Pedullá E, Grande E, Plotino G, Gambarini G, Rapisarda E. Influence of continuous or reciprocating motion on cyclic fatigue resistance of 4 different nickel-titanium rotary instruments. J Endod 2013;39:258-61. https://doi.org/10.1016/j.joen.2012.10.025

63. Kim H, Kwak S, Cheung GS, Ko D, Chung S, Lee W. Cyclic fatigue and torsional resistance of two new nickel-titanium instruments used in reciprocation motion:Reciproc versus WaveOne. J Endod 2012;38: 541-4. https://doi.org/10.1016/j.joen.2011.11.014 